\title{
CHEMICAL DEVELOPMENT IN UTERO
}

\author{
BY \\ E. M. WIDDOWSON and C. M. SPRAY \\ From the Medical Research Council and Department of Experimental Medicine, Cambridge
}

(Received for Publication June 9, 1950)

In spite of the spectacular advances in scientific medicine which we have witnessed in the last 20 years, there is still a need for information about a number of fundamental, if quite elementary, matters. One of these is the chemical composition of the human body. A knowledge of the quantitative make-up of the bodies of men, women, and children in both health and disease is of value for investigations of the most diverse types, but much of the information available is the result of guess work rather than chemistry. It is proposed to describe the results of an attempt to fill some of the gaps in our knowledge.

Von Bezold $(1857,1858)$ was the first to make an analysis of a human foetus. It weighed $523 \mathrm{~g}$., and he determined both organic and inorganic constituents. During the next 50 years a number of analyses were made, mostly in Germany and France, though one paper from Italy and one from Holland were published. Fehling (1877) studied 21 foetuses varying in weight from 1 to $3,294 \mathrm{~g}$. He was interested only in the amounts of water, nitrogen, and fat, but most workers included inorganic constituents in their analyses (Brubacher, 1891; Giacosa, 1895; Michel, 1899; Hugounenq, 1899, 1900a, b; de Lange, 1900; Camerer, 1900a, b, 1902; Söldner, 1903; Steinitz, 1904; Langstein and Edelstein, 1917). Further data have been provided by Givens and Macy (1933), who analysed 25 foetuses of various ages for water, ash, calcium, and magnesium, and Iob and Swanson (1934), who estimated water, fat, nitrogen, sodium, potassium, calcium, magnesium, phosphorus, and chloride in 17 foetuses weighing between $1 \cdot 7$ and 2,915 $\mathrm{g}$. Macy and Hunscher (1934), Coons, Schiefelbusch, Marshall, and Coons (1935) and Garry and Stiven (1936) took all these figures for the chemical composition of the human foetus into consideration in making their calculations of the dietary requirements of the mother during pregnancy and lactation.

Several studies of the chemical composition of the human placenta have been recorded. Full-term placentae have been analysed for water, nitrogen, fat, and ash by Higuchi (1909) and by Pratt,
Kaucher, Richards, Williams and Macy (1946). The amino-acids were studied by Koelker and Slemons (1911) and the different fatty constituents by Pratt, Kaucher, Moyer, Richards, and Williams (1946). Masters and Clayton (1940) were particularly interested in the amount of calcium in the placenta at different stages of maturity and Hilgenberg (1930) in the concentration of iron. These workers confined their studies to the placenta, and no parallel investigation of foetuses and placentae ever appears to have been made.

In the present study 19 human foetuses and fullterm infants have been analysed for nitrogen, fat. sodium, potassium, calcium, magnesium, phosphorus, iron, copper, and zinc, and the iodine in a number of thyroid glands was determined. Placentae from 12 of the foetuses were also analysed.

\section{Material}

Thirteen immature foetuses, two of which were twins, six stillborn infants weighing more than 3,000 g., and 12 placentae were obtained through the courtesy of the staff of Addenbrooke's Hospital and the County Maternity Hospital, Mill Road, Cambridge. Details as to foetal ages, sex and weights, and the cause of death are given in Table 1. Age was assessed by measurement of footlength (Streeter, 1920), but this and all other methods are acknowledged to be uncertain, and the chemical findings have therefore all been related to body weight. The livers and spleens were analysed separately from the rest of the body. The thyroid glands of 16 of the foetuses were sent by post to Miss B. W. Simpson, Rowett Research Institute, Aberdeen, for the determination of iodine. The amount of iodine was also determined in the thyroid glands from 16 children between birth and one year, and from 10 older children and three adults. These glands were removed at post-mortem examination at Addenbrooke's Hospital.

Preparation for Analysis. The bodies were weighed as soon after delivery as possible, and dissected on an enamel tray so that no blood was lost. The livers and spleens were removed and washed with distilled water, and the washings were added to the main sample. The thyroid glands were dissected out and weighed. The bodies, together with all the washings, were brought into solution with $\mathrm{HCl}$ as described by Venn, McCance, and 
TABLE 1

Description OF Material

\begin{tabular}{|c|c|c|c|c|c|c|}
\hline $\begin{array}{l}\text { Foetus } \\
\text { No. }\end{array}$ & Sex & $\begin{array}{l}\text { Approximate } \\
\text { Foetal Age } \\
\text { (weeks) }\end{array}$ & $\begin{array}{l}\text { Weight } \\
\text { (g.) }\end{array}$ & $\begin{array}{l}\text { Age of } \\
\text { Mother } \\
\text { (years) }\end{array}$ & $\begin{array}{l}\text { Parity } \\
\text { of } \\
\text { Mother }\end{array}$ & Cause of Death \\
\hline $\begin{array}{c}1 \text { (P) } \\
2 \text { and } 3 \\
\text { (twins) } \\
\text { (P) }\end{array}$ & $\begin{array}{c}\text { M. } \\
\text { Both } \\
\text { M. }\end{array}$ & $\begin{array}{l}17 \\
17\end{array}$ & $\left.\begin{array}{l}225 \\
227 \\
247\end{array}\right\}$ & $\begin{array}{l}26 \\
17 \frac{1}{2}\end{array}$ & $\stackrel{?}{1}$ & $\begin{array}{l}\text { Hysterotomy } \\
\text { Inevitable abortion }\end{array}$ \\
\hline $\begin{array}{l}4 \text { (P) } \\
5 \text { (P) } \\
6 \\
7 \text { (P) } \\
8\end{array}$ & $\begin{array}{l}\text { M. } \\
\text { F. } \\
\text { M. } \\
\text { M. } \\
\text { M. }\end{array}$ & $\begin{array}{l}19 \\
22 \\
22 \\
23 \\
24\end{array}$ & $\begin{array}{l}286 \\
400 \\
478 \\
673 \\
787\end{array}$ & $\begin{array}{l}3 ? \\
21 \\
36 \\
39\end{array}$ & $\begin{array}{l}? \\
6 \\
1 \\
1 \\
?\end{array}$ & $\begin{array}{l}\text { Ante-partum haemorrhage } \\
\text { Habitual abortion } \\
\text { Hysterotomy } \\
\text { Hysterotomy } \\
\text { Hysterotomy and ovariectomy for carcinoma } \\
\text { of ovaries }\end{array}$ \\
\hline $\begin{array}{l}9 \text { (P) } \\
10 \text { (P) } \\
11 \text { (P) } \\
12 \\
13 \\
14 \text { (P) } \\
15 \text { (P) } \\
16 \\
17 \\
18 \text { (P) } \\
19 \text { (P) }\end{array}$ & $\begin{array}{l}\text { M. } \\
\text { F. } \\
\text { M. } \\
\text { F. } \\
\text { M. } \\
\text { F. } \\
\text { F. } \\
\text { M. } \\
\text { F. } \\
\text { M. } \\
\text { M. }\end{array}$ & $\begin{array}{l}26 \\
30 \\
32 \\
33 \\
34 \\
34 \\
37 \\
37 \\
39 \\
40 \\
40\end{array}$ & $\begin{array}{r}911 \\
1,718 \\
1,966 \\
2,295 \\
2,652 \\
3,090 \\
3,767 \\
3,105 \\
3,050 \\
4,375 \\
3,994\end{array}$ & $\begin{array}{r}34 \\
36 \\
41 \\
24 \\
35 \\
21 \\
23 \\
? \\
? \\
36 \\
31\end{array}$ & $\begin{array}{l}7 \\
4 \\
3 \\
? \\
4 \\
1 \\
1 \\
? \\
? \\
5 \\
6\end{array}$ & $\begin{array}{l}\text { Hysterotomy } \\
\text { Surgical induction } \\
\text { Placenta praevia } \\
\text { Ante-partum haemorrhage } \\
\text { Breech presentation } \\
\text { Eclampsia } \\
\text { Unknown } \\
\text { Hydrocephalic } \\
\text { Placenta praevia }\end{array}$ \\
\hline
\end{tabular}

$(P)=$ placenta analysed.

Widdowson (1947). The livers and spleens were weighed and chopped up finely with a stainless steel knife. Weighed portions were taken for the determination of inorganic iron, and for ashing before the estimation of the metallic constituents. The remainder, a known proportion of the whole, was digested with $\mathrm{HCl}$ and used for the determination of nitrogen, phosphorus, and fat.

The placentae were drained as free from blood as possible, rapidly washed in distilled water and dried on blotting paper before being weighed. They were brought into solution in $\mathrm{HCl}$ and subsequently treated exactly as the other material.

Chemical Methods. The chemical methods used for the determination of nitrogen, fat and inorganic constituents are described by Spray and Widdowson (1950). The method of Harvey (1935) was used for the iodine estimations.

\section{The Chemical Composition of the Human Foetus and Full-term Infant}

Protein, Fat, and Water. Fig. 1 shows the total amounts of fat and protein in each individual foetus, Fig. 2 the percentages of these substances in the whole body, and Fig. 3 the percentages of protein and water calculated on a fat-free basis. These results emphasize (a) the enormous increase in the proportion of fat, from less than $1 \%$ in the early stages to over $28 \%$ in one full-term infant; and (b) the decrease in the proportion of water and the corresponding increase in the proportion of protein when expressed on a fat-free basis. If the protein is calculated as a percentage of the whole body (Fig. 2), the concentration increases till the foetus weighs about 3,000 g., and then decreases again,

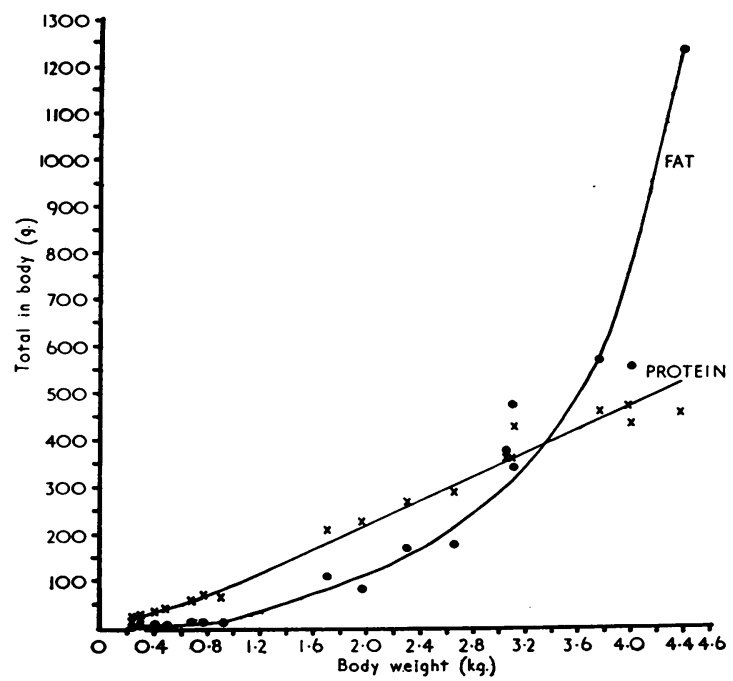

Fig. 1.--Total amounts of fat and protein in the foeta bodies. 
because from that stage onwards the increase in fat is greater than the decrease in water. The foetus

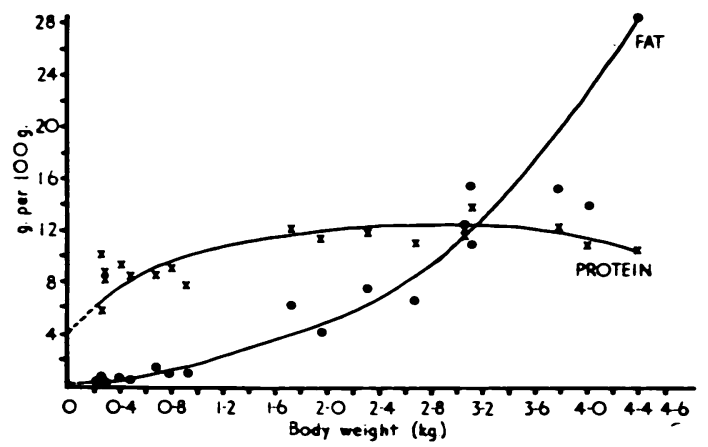

Fig. 2-Percentage of fat and protein in the foetal bodies.

begins to lay down fat when it weighs $800-1,000 \mathrm{~g}$. By the time it is $3,000 \mathrm{~g}$. the amount of fat in its body is approximately equal to the amount of protein. Thereafter the fat increases very rapidly indeed, so that a baby with a birth weight of $4,000 \mathrm{~g}$. is likely to have about $400 \mathrm{~g}$. more fat than one which weighed $3,000 \mathrm{~g}$. although it would only contain about $100 \mathrm{~g}$. more protein.

Previous workers who have aetermined the protein, fat, and water have devoted their attention mainly to foetuses in the early stages of development. For example, of the 21 foetuses analysed by Fehling (1877), 17 weighed less than 1,000 g., and five of the seven studied by Michel (1899) were under $700 \mathrm{~g}$. in weight. In fact, only five foetuses weighing more than $3,000 \mathrm{~g}$. ever appear to have been analysed for these constituents, and the beaviest of these was $3,360 \mathrm{~g}$. Of the present series, six weighed more than $3,000 \mathrm{~g}$. and three more than $3,360 \mathrm{~g}$. While the older work, therefore, is useful in indicating the composition of the foetus during the first few months of intra-uterine life, the present study gives a better picture of the chemical make-up of the full-term baby than any previously made.

The convention in the past has always been to make an assessment of the foetal age and to relate the chemical composition of the body to it. If the results of previous workers for water, protein, and fat are plotted against weight as in the present series (Figs. 1, 2 and 3), curves very similar in shape are obtained in the early stages. The smallest embryos ever analysed, weighing only a gram or so, contained about $4 \%$ of protein, $0.4 \%$ of fat, and $95.5 \%$ of water, and the curves in Fig. 2 have been extended to include these values. On the other hand it appears that the figure of $12 \%$ given by Shohl (1939) for the average percentage of fat in a baby at birth is too low. Shohl used all the available data in arriving at this figure, but the weight of his 'newborn' infant, $2.9 \mathrm{~kg}$. (6 lb. $6 \mathrm{oz}$.), is rather low for the average weight of a full-term baby. Five of the six foetuses weighing more than $3,000 \mathrm{~g}$. in the present study had more than $12 \%$ of fat in their bodies.

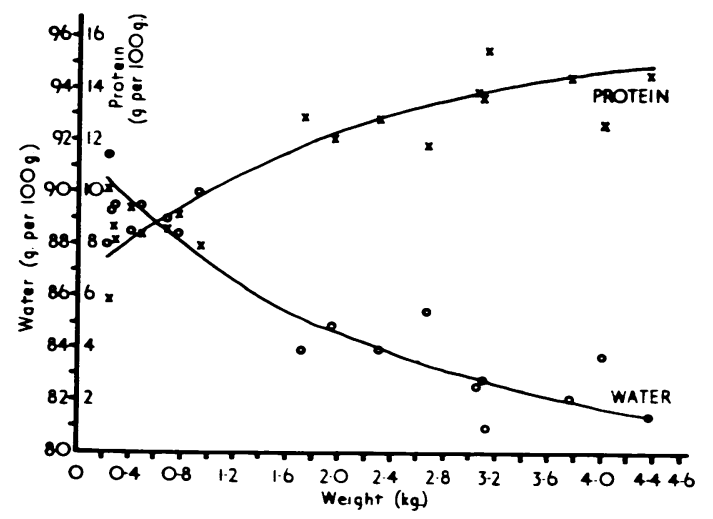

Fig. 3.-Protein and water (g. per $100 \mathrm{~g}$. of fat-free body tissue).

Sodium and Potassium. It is now generally taught that the proportion of sodium in the fat-free body tissue decreases during growth, both before birth and afterwards, and that this fall is brought about by a decrease in the fraction of the body occupied by extracellular fluids (Shohl, 1939). In Fig. 4 are shown the total amounts of sodium and potassium in the foetuses analysed in the present investigation, and in Fig. 5 the amounts of these elements per $100 \mathrm{~g}$. of fat-free body tissue. The concentration of sodium was rather variable. It tended to decrease in the early stages, but from the time the foetus weighed $2,000 \mathrm{~g}$. it was approximately constant at about $220-225 \mathrm{mg}$. per $100 \mathrm{~g}$., and this

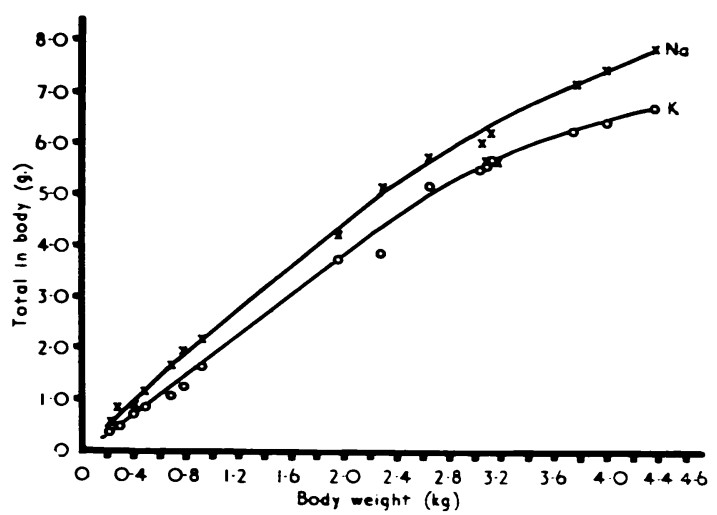

Fig. 4.-Total amounts of sodium and potassium in the foetal bodies. 
was also the value found for the concentration of sodium in the fat-free tissue of the human adult

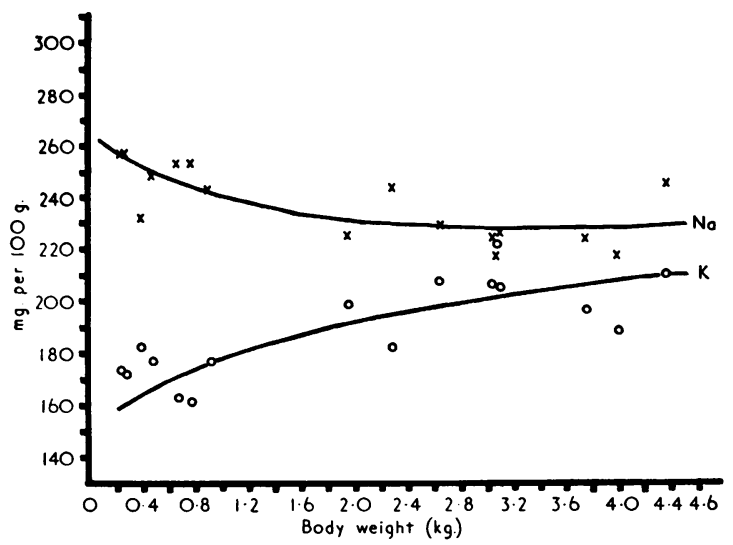

FIG. 5.-Sodium and potassium (mg. per 100 g. of fat-free body tissue).

(Widdowson, McCance, and Spray, 1950). These results seem to be a direct contradiction of the view which is commonly held at the present time. There is no doubt that the proportion of extracellular fluids does fall (Fellers, Barnett, Hare, and McNamara, 1949), and with it the proportion of extracellular fluid sodium in the body. It is quite clear from the work of Harrison, Darrow, and Yannet (1936), however, that about $50 \%$ of the sodium in the body of the adult monkey, dog, and rabbit is in the skeleton, and that half of this is present as an insoluble or undissociated compound which contributes little if anything to the osmotic pressure of skeletal water. The same is probably true of the human adult, and Widdowson et al. (1950) have obtained some direct confirmatory evidence. Harrison et al. made some calculations from the data of Iob and Swanson (1934) of the total and extracellular sodium in the bodies of human foetuses of various weights, and have shown that, whereas in a foetus weighing $340 \mathrm{~g}$. the extracellular sodium accounts for $97.5 \%$ of the total sodium in the body, by the time the foetus weighs $2,970 \mathrm{~g}$., only $76 \%$ of the sodium in the body is in the extracellular fluids. It appears that, from the seventh month of prenatal life onwards, the fall in the proportion of extracellular sodium is just about counterbalanced by the increase in the amount of sodium being deposited in the skeletal tissues.

The concentration of potassium in the fat-free body tissue increased during intra-uterine life, but it was always lower than the concentration of sodium, and the infant at full term contained about 200-210 mg. of potassium per $100 \mathrm{~g}$. of fat-free body tissue. Shohl's (1939) figure for the concentration of potassium in the fat-free tissue of a newborn baby is $190 \mathrm{mg}$. per $100 \mathrm{~g}$. but it is probable that his newborn baby was not really mature. Nearly all the potassium in the human body is in the cells, and the concentration in the whole body is what one would expect from a knowledge of the volume of intracellular water and the concentration of potassium in it (Harrison et al., 1936). Thus the concentration of potassium in the whole body increases in proportion to the increase in cell mass and the value for the concentration of potassium in the human adult (Widdowson et al., 1950) is considerably higher than the present figure for the infant at term.

Calcium, Phosphorus, and Magnesium. Fig. 6

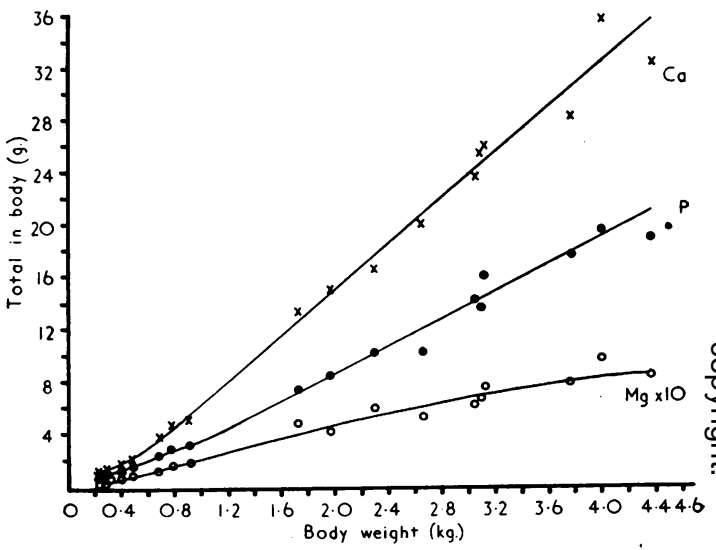

FIG. 6.-Total amounts of calcium, magnesium, and phosphorus in the foetal bodies.

shows the total amounts of calcium, phosphorus, and magnesium in the foetal bodies, and Fig. 7 the percentages of these elements on a fat-free basis. The absolute amounts of all three elements showed a steady increase with increasing weight so that the full-term infants contained 20 or 30 times more of each than the foetuses weighing $225 \mathrm{~g}$. or so. The percentages also increased, the concentration of calcium at full term being rather more than twice, and of phosphorus a little less than twice as high as it was in the smallest foetuses examined. The concentration of magnesium rose in the early stages, but remained almost constant in foetuses weighing 2,000 g. and over.

Early investigators who determined the calcium, magnesium, and phosphorus in the human foetus did not always give the percentage of fat, so their figures cannot be compared with those shown in Fig. 7. If the results previously published for the total amounts of calcium, magnesium, and phosphorus in human foetuses are plotted against body weights, curves similar to those in Fig. 6 are obtained, but 
during the past 30 years only one foetus weighing more than 1,615 g. has been analysed. Coons et al.

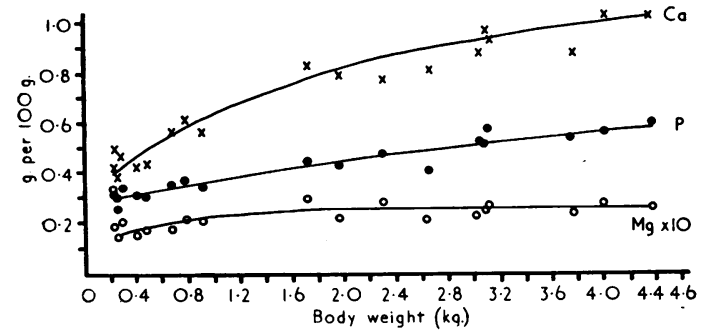

FIG. 7.-Calcium, magnesium, and phosphorus (g. per $100 \mathrm{~g}$. of fat-free body tissue).

(1935) and Garry and Stiven (1936) took Michel's (1899) data for a foetus weighing $3,335 \mathrm{~g}$. to represent the composition of the human infant at term, but Michel's figures for all three elements are considerably higher than those shown in Fig. 6 for a foetus of a similar size. Booher and Hansmann (1931) analysed the tibiae of newborn infants and found the proportion of calcium in these bones to be nearly constant when expressed on a dry fat-free basis, irrespective of the calcium intake or age of the mother. They suggested that the composition of the skeleton is constant, and that variations only appear when the results for calcium are expressed as a percentage of the whole body.

It is due to the progressive calcification of the bones, which have a $\mathrm{Ca} / \mathrm{P}$ ratio of over 2 that the $\mathrm{Ca} / \mathrm{P}$ ratio of the whole body tends to rise as development proceeds, particularly during the first seven months or so of intra-uterine life (Fig. 8),

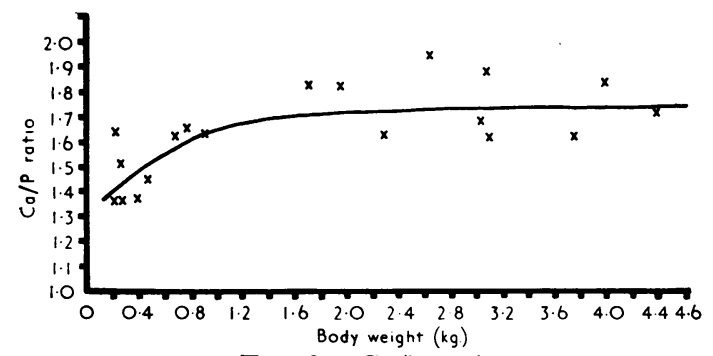

Fig. 8. $-\mathrm{Ca} / \mathrm{P}$ ratios.

but three foetuses which weighed $600-900 \mathrm{~g}$. had ratios as high as two others which weighed over 3,000 g. Iob and Swanson's (1934) ratios were equally irregular. The ratio at term is probably between 1.7 and 1.8 , and this was the value found by Widdowson et al. (1950) for the human adult.

Iron, Copper, and Zinc. The total amounts of iron and zinc in the whole foetal bodies are shown in Fig. 9 and of copper in Fig. 10. The quantity of iron was rather variable in the full-term infants, but no figure approaching the $937 \mathrm{mg}$. given by Garry and Stiven (1936) was obtained. Very few whole bodies have been analysed for iron in the past. Hugounenq (1899) was particularly interested in this element and his results fit in much better with the present series than those of Camerer (1902). Camerer, whose values are higher than our own, himself suspected that his samples were contaminated with iron. Fullerton (1937) assessed the

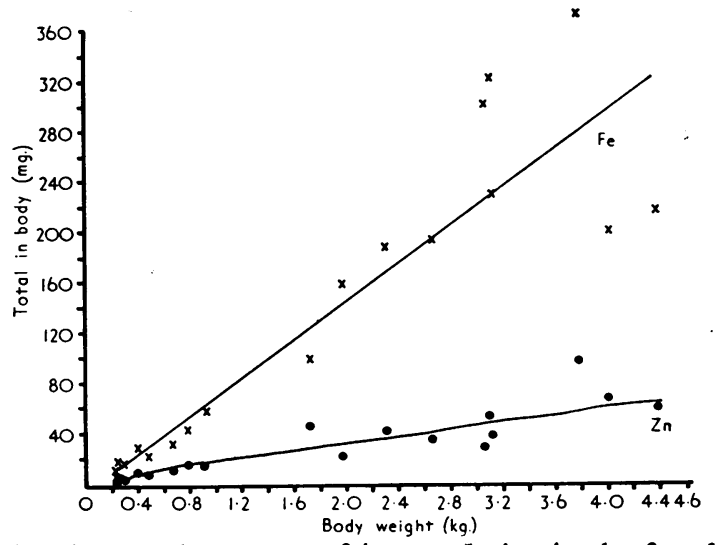

FIG. 9.-Total amounts of iron and zinc in the foetal bodies.

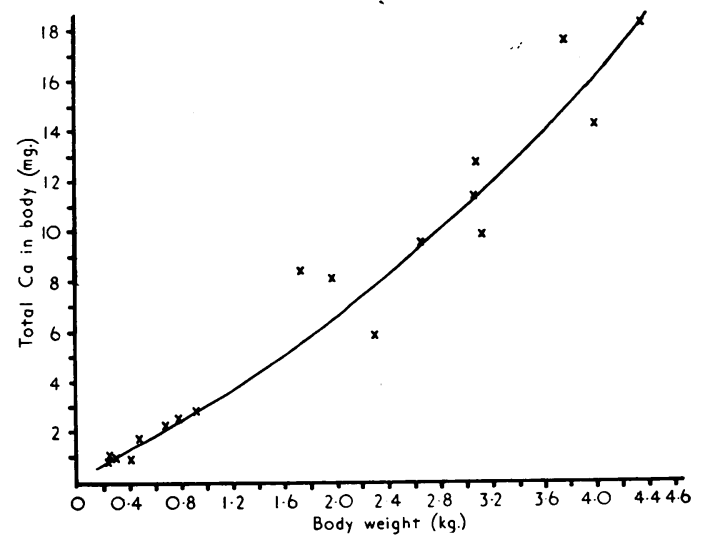

FIG. 10.-Total amounts of copper in the foetal bodies.

amount of iron in a full-term baby from published figures for blood volumes and haemoglobin levels, and his estimate was $450 \mathrm{mg}$. This is higher than any of the present series and there is reason to believe that it is too high (McCance and Widdowson, 1951). The average for the six infants weighing more than $3,000 \mathrm{~g}$. in this investigation was $273 \mathrm{mg}$. How this lower value for the iron in the full-term foetus affects any theory about the development of suckling anaemia is discussed by McCance and Widdowson (1951). 
No information about the amounts of copper and zinc in foetal bodies has hitherto been published.

The quantities of iron and zinc per $100 \mathrm{~g}$. of fat-free body substance are given in Fig. 11, and

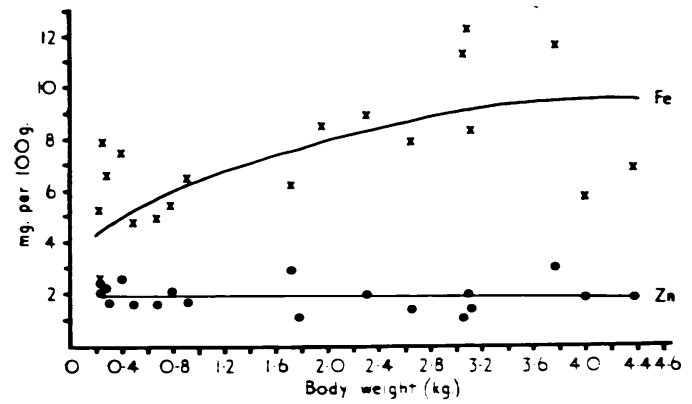

Fig. 11.-Iron and zinc in the foetal bodies (mg. per $100 \mathrm{~g}$. of fat-free body tissue).

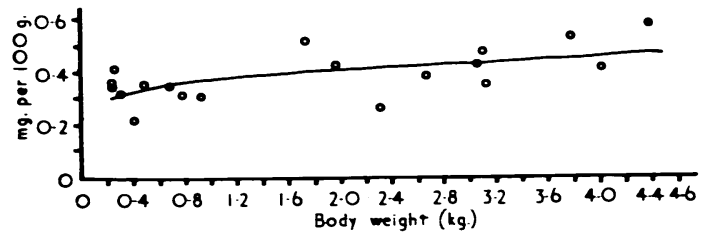

Fig. 12.-Copper in the foetal bodies (mg. per $100 \mathrm{~g}$. of fat-free body tissue).

of copper in Fig. 12. The concentrations of iron and copper tended to be a little higher in the larger foetuses, but the two biggest contained no more iron per $100 \mathrm{~g}$. than some of the smallest ones. This implies that no large store of iron is accumulated by the human foetus shortly before birth (McCance and Widdowson, 1951). The 'concen- tration' of zinc did not change throughout intrauterine life and the increase in total amount exactly paralleled the increase in body weight.

Table 2 shows the concentration of inorganic iron, copper, and zinc in the liver and spleen, and the percentage of the total amount in the body present in these organs. The results were irregular, but of the same order for iron and copper whatever the age and size of the foetus. The liver and spleen always contained about the same proportion of the body's iron, copper, and zinc. Roughly speaking. about one half of the copper, one quarter of the zinc, and one eighth of the iron in the body was found in these two organs. If the results shown in Figs. 11 and 12 are compared with the values given in Table $\dot{2}$ it will be seen that the concentration of iron was about twice, the concentration of zinc about 10 times, and that of copper 20 or 30 times as high in the liver and spleen as in the body as a whole.

Several workers have analysed the livers of stillborn infants for inorganic iron or for total iron in the blood-free organ (Adler and Adler, 1931; Gladstone, 1932; Toverud, 1935; Schairer and Rechenberger, 1943). Their assessments ranged from about 30 to $60 \mathrm{mg}$. of iron in the whole liver Stearns and McKinley (1937) suggested that the amount might be much less if the mother's diet had been deficient in iron. The present values for the foetuses weighing more than 3,000 g. varied from $11 \cdot 5$ to $51 \cdot 4 \mathrm{mg}$. Brückmann and Zondek (1939) determined both iron and copper in the livers of five newborn infants. Their findings for iron varied from 8.8 to $58.8 \mathrm{mg}$. per $100 \mathrm{~g}$. and for copper from $1 \cdot 2$ to $6 \cdot 9 \mathrm{mg}$. per $100 \mathrm{~g}$. It will be seen from

TABle 2

Distribution of Inorganic Fe, Cu, and $Z_{N}$ in the foetal Bodies

\begin{tabular}{|c|c|c|c|c|c|c|}
\hline \multirow{2}{*}{$\begin{array}{l}\text { Weight of } \\
\text { Foetus (g.) }\end{array}$} & \multicolumn{3}{|c|}{$\begin{array}{l}\text { Distribution in Liver and Spleen } \\
\text { (mg. per } 100 \mathrm{~g} .)\end{array}$} & \multicolumn{3}{|c|}{$\begin{array}{l}\text { Percentage of the Body's } \mathrm{Fe}, \mathrm{Cu} \text {, and } \mathrm{Zn} \text { in } \\
\text { Liver and Spleen }\end{array}$} \\
\hline & Inorganic Fe & $\mathrm{Cu}$ & $\mathbf{Z n}$ & Inorganic Fe & $\mathrm{Cu}$ & $\mathbf{Z n}$ \\
\hline $\begin{array}{r}225 \\
227 \\
247 \\
286 \\
673 \\
787 \\
911 \\
1,718 \\
1,966 \\
2,295 \\
3,050 \\
3,090 \\
3,105 \\
3,994 \\
4,375\end{array}$ & $\begin{array}{c}- \\
\bar{Z} \\
20 \cdot 4 \\
8 \cdot 5 \\
6 \cdot 8 \\
30 \cdot 0 \\
\overline{20 \cdot 0} \\
19 \cdot 9 \\
37 \cdot 0 \\
25 \cdot 5 \\
10 \cdot 4 \\
21 \cdot 1 \\
16 \cdot 7\end{array}$ & $\begin{array}{l}-\overline{2} \cdot 03 \\
1 \cdot 53 \\
4 \cdot 12 \\
4 \cdot 07 \\
5 \cdot 28 \\
4 \cdot 62 \\
8 \cdot 70 \\
4 \cdot 80 \\
2 \cdot 58 \\
2 \cdot 42 \\
3 \cdot 92 \\
3 \cdot 83 \\
4 \cdot 60 \\
6 \cdot 00\end{array}$ & $\begin{array}{r}32 \cdot 9 \\
11 \cdot 9 \\
10 \cdot 8 \\
17 \cdot 2 \\
17 \cdot 7 \\
14 \cdot 6 \\
20 \cdot 7 \\
19 \cdot 1 \\
8 \cdot 7 \\
10 \cdot 0 \\
6 \cdot 1 \\
5 \cdot 1 \\
5 \cdot 4 \\
9 \cdot 0 \\
8 \cdot 7\end{array}$ & $\begin{array}{r}- \\
\overline{16} \\
7 \\
4 \\
19 \\
14 \\
10 \\
17 \\
15 \\
5 \\
19 \\
14\end{array}$ & $\begin{array}{l}-17 \\
14 \\
66 \\
48 \\
46 \\
62 \\
69 \\
64 \\
43 \\
29 \\
58 \\
46 \\
58 \\
61\end{array}$ & $\begin{array}{l}58 \\
17 \\
21 \\
53 \\
43 \\
20 \\
51 \\
27 \\
43 \\
23 \\
28 \\
18 \\
17 \\
24 \\
27\end{array}$ \\
\hline
\end{tabular}


Table 2 that these figures are of the same order as our own. The amount of zinc in the human liver does not seem to have been investigated hitherto.

\section{Iodine in the Thyroid Ghad}

The results of the determinations of iodine are set out in Table 3. The concentration of iodine in the thyroid gland was variable from one individual to another, but there was an increase with increasing age. The average for foetuses weighing less than $1,000 \mathrm{~g}$. (omitting the pair of twins) was $2 \cdot 4 \mathrm{mg}$. per $100 \mathrm{~g}$. and for those weighing more than $1,000 \mathrm{~g}$. was $3.1 \mathrm{mg}$. per $100 \mathrm{~g}$. The average value for the children below one year was $7 \cdot 8$, for the older children 19.2 and for the three adults $41.7 \mathrm{mg}$. per $100 \mathrm{~g}$. Koneff, Nichols, Wolff, and Chaikoff (1949) have shown that the concentration of iodine in the thyroid of the foetal calf increases progressively with age and have postulated that the foetal thyroid acquires an increased capacity for collecting and storing iodine. The present findings for the human foetus would not be a contradiction of this, and the same process may go on in extra-uterine life.

One point of interest about the present series of thyroids from full-term infants is their size. The human thyroid generally weighs $1 \mathrm{~g}$. at birth (B. W. Simpson, personal communication), though
Ekholm and Niemenera (1950), working in Finland, reported weights ranging from $1 \cdot 65$ to $3 \cdot 18 \mathrm{~g}$. for the thyroid glands of foetuses weighing between 1,250 and 2,500 g. These authors emphasize the great variability in the weights of the thyroids of foetuses of the same size. All six of the foetuses in the present series weighing more than $2,000 \mathrm{~g}$. had thyroids weighing more than $1 \mathrm{~g}$. and the glands of four of them weighed more than $2 \mathrm{~g}$. One of the newborn infants had a grossly enlarged thyroid, weighing 8.6 g., and a girl of 4 also had one which was abnormally heavy (6.9 g.). Both these thyroids contained very low 'concentrations' of iodine, and there was less iodine in these glands than in those of other children of similar age. All the foetuses and children with the enlarged glands came from Cambridge or the country nearby, and the material was collected during the years 1944 and 1945.

\section{Composition of the Human Placenta}

Table 4 shows the percentage composition of the 12 placentae which were analysed. Figures for iron have been omitted because, although most of the blood was removed, it is certain that some still remained, and the values for iron would have been greatly influenced by the amount of residual blood.

The placental weights did not necessarily follow the foetal weights, and the largest foetus had a

TABuE 3

Analyses of IODINe In the Thyroid Gland

\begin{tabular}{|c|c|c|c|c|c|c|c|c|c|c|c|}
\hline \multirow[b]{2}{*}{$\begin{array}{c}\text { Approx. } \\
\text { Foetal } \\
\text { Age } \\
\text { (weeks) }\end{array}$} & \multicolumn{3}{|c|}{ Foetuses } & \multicolumn{4}{|c|}{ Infants under 1 year } & \multicolumn{4}{|c|}{ Children over 1 year and Adults } \\
\hline & $\begin{array}{l}\frac{\tilde{5}}{0} \\
\frac{5}{3} \\
\text { ㅎํㅇ }\end{array}$ & 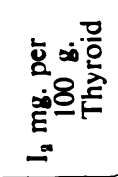 & 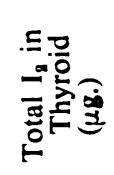 & $\sum^{\infty}$ & 希 & 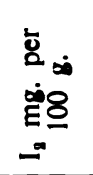 & 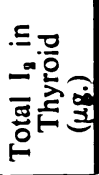 & 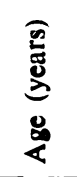 & শ্口 & 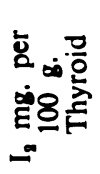 & 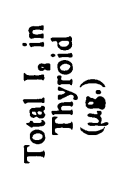 \\
\hline \multicolumn{12}{|l|}{ Twins } \\
\hline $\begin{array}{l}17 \\
17 \\
19 \\
22\end{array}$ & $\begin{array}{l}227 \\
247 \\
286 \\
400\end{array}$ & $\begin{array}{l}0 \cdot 8 \\
0 \cdot 04 \\
4 \cdot 0 \\
1 \cdot 4\end{array}$ & $\begin{array}{l}0 \cdot 29 \\
0 \cdot 01 \\
6 \cdot 8 \\
2 \cdot 5\end{array}$ & $\begin{array}{c}\text { Newborn } \\
\text { ", } \\
5 \text { days }\end{array}$ & $\begin{array}{l}\text { F. } \\
\text { M. } \\
\text { F. } \\
\text { M. }\end{array}$ & $\begin{array}{r}14 \cdot 0 \\
4 \cdot 0 \\
0 \cdot 3 \\
6 \cdot 0\end{array}$ & $\begin{array}{r}134 \\
46 \\
26 \\
51\end{array}$ & $\begin{array}{l}1 \\
1 \frac{1}{2} \\
2 \\
3 \frac{1}{2}\end{array}$ & $\begin{array}{l}\text { F. } \\
\text { M. } \\
\text { M. } \\
\text { F. }\end{array}$ & $\begin{array}{l}12 \cdot 0 \\
14 \cdot 0 \\
12 \cdot 0 \\
13 \cdot 0\end{array}$ & $\begin{array}{l}156 \\
321 \\
312 \\
460\end{array}$ \\
\hline 22 & 478 & $1 \cdot 5$ & $3 \cdot 8$ & 6 days & F. & $8 \cdot 0$ & 67 & 4 & M. & $39 \cdot 0$ & 940 \\
\hline $\begin{array}{l}23 \\
24 \\
26 \\
30 \\
32 \\
33 \\
34 \\
34 \\
37 \\
40 \\
40\end{array}$ & $\begin{array}{r}673 \\
787 \\
911 \\
1,718 \\
1,966 \\
2,295 \\
2,652 \\
3,090 \\
3,767 \\
3,994 \\
4,375\end{array}$ & $\begin{array}{l}6 \cdot 0 \\
0 \cdot 9 \\
0 \cdot 5 \\
3 \cdot 0 \\
0 \cdot 6 \\
2 \cdot 0 \\
1 \cdot 2 \\
8 \cdot 0 \\
3 \cdot 3 \\
0 \cdot 3 \\
6 \cdot 0\end{array}$ & $\begin{array}{r}12 \cdot 3 \\
4 \cdot 8 \\
3 \cdot 2 \\
24 \cdot 3 \\
5 \cdot 9 \\
45 \cdot 3 \\
24 \cdot 9 \\
131 \cdot 0 \\
111 \cdot 4 \\
7 \cdot 9 \\
105 \cdot 2\end{array}$ & $\begin{array}{l}15 \text { days } \\
24 \text { days } \\
2 \text { months } \\
2 \quad,, \\
2 \quad,, \\
2 \frac{1}{2},, \\
2 \frac{1}{2},, \\
3 \quad, \\
4 \quad, \\
6 \quad, \\
7 \quad,\end{array}$ & $\begin{array}{l}\text { F. } \\
\mathbf{M} . \\
\text { F. } \\
\text { M. } \\
\text { F. } \\
\mathbf{M} . \\
\mathbf{M} . \\
? \\
\mathbf{M} . \\
\mathbf{F} . \\
\mathbf{M} .\end{array}$ & $\begin{array}{r}6 \cdot 0 \\
13 \cdot 0 \\
2 \cdot 7 \\
13 \cdot 0 \\
7 \cdot 6 \\
18 \cdot 0 \\
9 \cdot 0 \\
9 \cdot 6 \\
5 \cdot 0 \\
3 \cdot 0 \\
6 \cdot 0\end{array}$ & $\begin{array}{r}107 \\
77 \\
36 \\
260 \\
69 \\
214 \\
112 \\
234 \\
140 \\
57 \\
79\end{array}$ & $\begin{array}{r}4 \\
5 \\
6 \\
6 \\
12 \\
21 \\
27 \\
31\end{array}$ & $\begin{array}{l}\text { F. } \\
\text { F. } \\
\text { M. } \\
\text { F. } \\
\text { F. } \\
\text { M. } \\
\text { F. } \\
\text { M. }\end{array}$ & $\begin{array}{r}2 \cdot 0 \\
34 \cdot 0 \\
15 \cdot 0 \\
13 \cdot 0 \\
38 \cdot 0 \\
27 \cdot 0 \\
40 \cdot 0 \\
58 \cdot 0\end{array}$ & $\begin{array}{r}139 \\
820 \\
805 \\
597 \\
2,810 \\
5,680 \\
5,050 \\
17,300\end{array}$ \\
\hline
\end{tabular}


TABLE 4

Compostion of Human Placentae

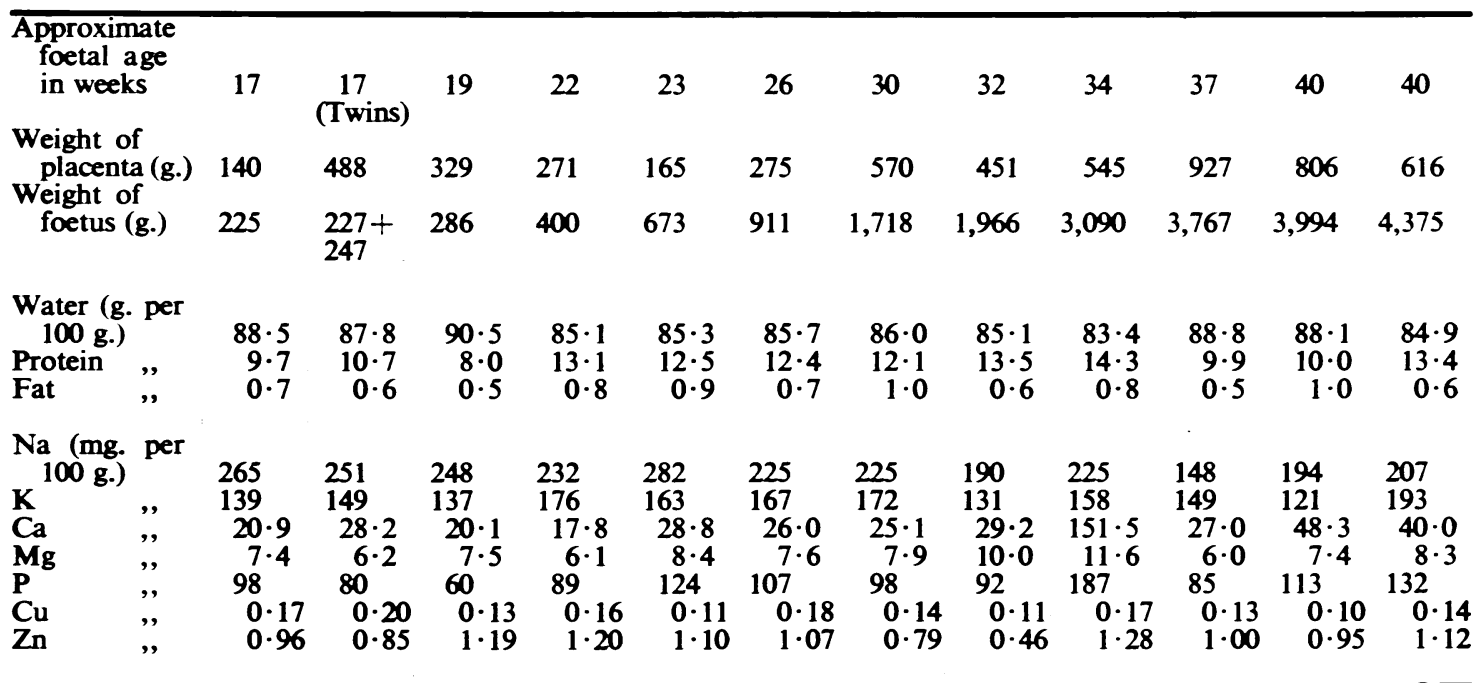

placenta which was very little heavier than that of a foetus weighing less than half as much. Other workers (Pratt et al. 1946) also found that weights of foetuses and placentae did not always run together.

The placenta is a very watery organ, and the percentage of water does not appear to be less at full term than it is earlier in pregnancy. Pratt et al. (1946), who analysed nine full-term placentae, found the moisture to vary from 85 to $94 \%$ with an average of $87 \%$. These figures agree very well with our own. The proportions of protein and fat also remained of the same order throughout. The protein and fat in the placentae of the four foetuses weighing more than $3,000 \mathrm{~g}$. averaged $11 \cdot 9^{\circ} \%$ and $0.7 \%$ respectively; the corresponding figures for the other placentae were $11 \cdot 5$ and $0.7 \%$.

The concentration of calcium in the placentae of the smaller foetuses was similar to that found by Masters and Clayton (1940). There was one high figure in the series, $151.5 \mathrm{mg}$. per $100 \mathrm{~g}$., from a 34-week pregnancy, and this placenta would probably have appeared calcified on x-ray examination. There was possibly an increase in the concentration of phosphorus with increasing age, but on the whole the mineral make-up altered little and, except for the calcification of the arteries, which is probably a sign of degeneration, it is clear that no changes in the composition of the placenta take place which are at all comparable with the alterations in the composition of the developing foetus.

At the seventeenth to the nineteenth week of pregnancy the foetus and its placenta were of approximately equal weight, and both contained similar amounts of nitrogen, fat, and potassium. The foetus contained more of all the other constituents, two to five times as much magnesium, phosphorus, copper, and zinc and 20 or 30 times as much calcium. During the last four months the foetus grows much more rapidly than the placenta so that at term it weighs five or six times as much. The concentrations of nitrogen and potassium remained very similar in both. At full term the concentrations of magnesium, phosphorus, copper, and zinc were two to four times as high in the foetus as in the placenta, the concentration of calcium between five and 30 times and of fat 25 times as high.

\section{Discussion}

From the results which have been obtained an estimate has been made of the probable composition of the body of a premature baby weighing $1,500 \mathrm{~g}$. ( $3 \frac{1}{2}$ lb.) and of one weighing $2,500 \mathrm{~g}$. ( $5 \frac{1}{2} \mathrm{lb}$.), compared with that of a full-term infant weighing 3,500 g. $\left(7 \frac{1}{2} \mathrm{lb}\right.$.). The values are set out in Tables 5 and 6. The outstanding deficiency of the premature baby is one of fat. The baby weighing $1,500 \mathrm{~g}$. contains only one-eighth as much fat as a full-term infant. Most mammalian species are born with only $1-2 \%$ of fat in their bodies, and the full-term human baby represents the exception in chemical composition rather than the rule. Widdowson (1950) has discussed various reasons for this difference in the composition at birth. The lack of subcutaneous fat in premature babies is, of course, well known to those responsible for their care 
(Crosse, 1945) and there is no doubt that the layer of fat beneath the skin is of great value to the human infant as an insulation against loss of heat. It is interesting to consider how the newborn of other species manage to survive without any subcutaneous fat at all (Thomas, 1911; Widdowson, 1950).

The values given in Table 5 represent the percentage composition of the whole body, and not as in Figs. 3, 5, 7, and 11 , the amounts per $100 \mathrm{~g}$. of fat-free body tissue. Since the proportion of fat in the body is greater the more mature the foetus, the lower the concentration of all the other constituents will tend to be when expressed as a percentage of the whole body in comparison with the same data expressed on a fat-free basis. This is well illustrated by a comparison of the curves for protein in Figs. 2 and 3.

TABLE 5

Comparison Between Percentage Composition of Premature Babies and a Full-term INfant

\begin{tabular}{|c|c|c|c|}
\hline & $\begin{array}{l}\text { Prema- } \\
\text { ture } \\
(1,500 \mathrm{~g} .)\end{array}$ & $\begin{array}{l}\text { Prema- } \\
\text { ture } \\
(2,500 \mathrm{~g} .)\end{array}$ & $\begin{array}{c}\text { Full } \\
\text { Term } \\
(3,500 \mathrm{~g} .)\end{array}$ \\
\hline 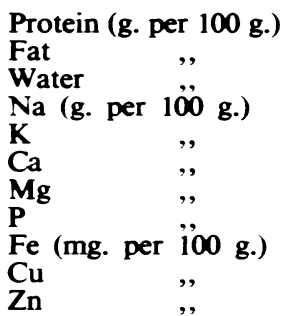 & $\begin{array}{l}11 \cdot 6 \\
3 \cdot 5 \\
82 \cdot 5 \\
0 \cdot 23 \\
0 \cdot 19 \\
0 \cdot 68 \\
0 \cdot 023 \\
0 \cdot 37 \\
7 \cdot 1 \\
0 \cdot 32 \\
1 \cdot 7\end{array}$ & $\begin{array}{l}12 \cdot 4 \\
7 \cdot 6 \\
77 \cdot 3 \\
0 \cdot 21 \\
0 \cdot 19 \\
0 \cdot 76 \\
0 \cdot 024 \\
0 \cdot 43 \\
7 \cdot 4 \\
0 \cdot 35 \\
1 \cdot 6\end{array}$ & $\begin{array}{l}12 \cdot 0 \\
16 \cdot 2 \\
68 \cdot 8 \\
0 \cdot 19 \\
0 \cdot 17 \\
0 \cdot 81 \\
0 \cdot 022 \\
0 \cdot 46 \\
7 \cdot 5 \\
0 \cdot 39 \\
1 \cdot 5\end{array}$ \\
\hline
\end{tabular}

TABLE 6

Total Amolnts of Various Constituents IN THE Bodies of Premature Babies Compared WITH those in A FUll-term BABY

\begin{tabular}{|c|c|c|c|c|c|}
\hline & 莺 & 总 & $\underset{\bar{\Xi}}{\stackrel{E}{E}}$ & 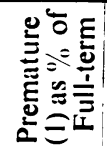 & 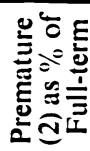 \\
\hline 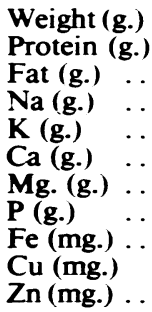 & $\begin{array}{c}1,500 \\
160 \\
60 \\
3 \cdot 50 \\
2 \cdot 80 \\
10 \cdot 2 \\
0 \cdot 35 \\
5 \cdot 6 \\
106 \\
4 \cdot 8 \\
26 \cdot 0\end{array}$ & $\begin{array}{c}2,500 \\
290 \\
200 \\
5 \cdot 35 \\
4 \cdot 70 \\
19 \cdot 0 \\
0 \cdot 60 \\
10 \cdot 8 \\
184 \\
8 \cdot 8 \\
40 \cdot 0\end{array}$ & $\begin{array}{c}3,500 \\
415 \\
470 \\
6 \cdot 75 \\
6 \cdot 00 \\
28 \cdot 2 \\
0 \cdot 76 \\
16 \cdot 2 \\
262 \\
13 \cdot 7 \\
53 \cdot 0\end{array}$ & $\begin{array}{l}43 \\
39 \\
13 \\
52 \\
47 \\
36 \\
46 \\
35 \\
41 \\
35 \\
49\end{array}$ & $\begin{array}{l}72 \\
70 \\
43 \\
80 \\
78 \\
68 \\
79 \\
67 \\
70 \\
64 \\
76\end{array}$ \\
\hline
\end{tabular}

The concentrations of protein, potassium, magnesium, and iron in the whole body are about the same whether the infant weighs $1,500 \mathrm{~g}$. Or $3,500 \mathrm{~g}$., and the proportion of the body occupied by cellular tissue, therefore, probably remains fairly constant at this stage of development. As the foetus lays down fat the extracellular fluids form a smaller and smaller fraction of the body and in spite of the deposition of sodium in the skeleton, the concentration of sodium in the whole body falls.

A premature baby not only has less calcium and phosphorus in its whole body than one which is born at full-term, but it also has less per $100 \mathrm{~g}$. body weight in spite of the fact that the full-term baby has so much more fat. The premature baby also appears to have a slightly smaller concentration of copper.

\section{Summary}

Thirteen immature foetuses and six stillborn infants weighing more than $3,000 \mathrm{~g}$. have been analysed for nitrogen, fat, sodium, potassium, calcium, magnesium, phosphorus, iron, copper, and zinc, and the iodine in the thyroid glands was determined. The placentae of 12 of the foetuses and infants were also investigated.

The foetus begins to lay down fat when it weighs $800-1,000 \mathrm{~g}$., and by the time it weighs $3,000 \mathrm{~g}$. the amount of fat in its body is approximately equal to the amount of protein $\left(12^{\circ} \%\right.$ ). After this the fat increases much more rapidly than the protein, and one stillborn infant which weighed $4,375 \mathrm{~g}$. contained $28^{\circ}$ of fat.

The concentration of sodium per $100 \mathrm{~g}$. of fat-free body tissue decreased until the foetal weight was about 2,000 g., and then remained constant until term. The value reached was the same as in adult life. The concentration of potassium in the fat-free body tissue increased throughout intrauterine life, but the concentration in the whole body altered little from the time the foetus began to lay down fat.

The concentration of calcium and phosphorus increased with increasing weight, so that the percentage of calcium at full term was rather more than twice and of phosphorus a little less than twice as high as it was in the foetuses weighing 200-300 g.

The percentage of iron and copper in the foetus increased with development while that of zinc did not change. The liver and spleen contained about one-half of the copper, one-quarter of the zinc, and one-eighth of the iron in the whole body.

The concentration of iodine in the thyroid appeared to increase during foetal life and after, and in the thyroids from three adults was about 20 times as high in those from the immature foetuses. 
At the seventeenth to nineteenth week of pregnancy the foetus and its placenta were of approximately equal weight, and contained similar amounts of nitrogen, fat, and potassium. During the last four months the foetus grows much more rapidly so that at full term it weighed five or six times as much as its placenta. The "concentrations" of nitrogen and potassium were similar in both, but those of fat, calcium, magnesium, phosphorus, copper, and zinc were all higher in the foetus than in its placenta.

We should like to take this opportunity of thanking Professor R. A. McCance for his wise encouragemenl throughout the investigation. We are also very grateful to Dr. R. F. A. Dean for his help in obtaining the bodies for analysis, and to Miss B. W. Simpson for making the iodine analyses.

\section{REFERENCES}

Adler, K., and Adler, M. (1931). Z. Geburtsh. Gynäk., $101,128$.

Bezold, A. von (1857). Z. wiss. Zool., 8, 487.

- (1858). Ibid., 9, 240.

Booher, L. E., and Hansmann, G. H. (1931). J. biol. Chem., 94, 195.

Brubacher, H. (1891). Z. Biol., 27, 517.

Brückmann, G., and Zondek, S. G. (1939). Biochem. J., 33, 1845.

Camerer, W. Jr. (1900a). Z. Biol., 39, 173.

(1900b). Ibid., 40, 529. (1902). Ibid., 43, 1.

Coons, C. M., Schiefelbusch, A. T., Marshall, G. B., and Coons, R. R. (1935). Oklahoma Agric. Mech. Coll., Agric. Exp. Sta. Bull., No. 223.

Crosse, V. M. (1945). 'The Premature Baby.' London.

Ekholm, E., and Niemenera, K. (1950). Acta. Paediatr., $39,67$.

Fehling, H. (1877). Arch. Gynäk., 11, 523.

Fellers, F. X., Barnett, H. L., Hare, K., and McNamara, H. (1949). Pediatrics, 3, 622.

Fullerton, H. W. (1937). Archives of Disease in Childhood, 12, 91.

Garry, R. C., and Stiven, D. (1936). Nutr. Abst. Rev., 5,855 .

Giacosa, G. (1895). Arch. ital. Biol., 22, 252.

Givens, M. H., and Macy, I. G. (1933). J. biol. Chem., 102, 7.
Gladstone, S. A. (1932). Amer. J. Dis. Child., 44, 81.

Harrison, H. E., Darrow, D. C., and Yannet, H. (1936). J. biol. Chem., 113, 515.

Harvey, C. O. (1935). Spec. Rep. Ser. med. Res. Coun., Lond., No. 201.

Higuchi, S. (1909). Biochem. Z., 15, 95.

Hilgenberg, F. C. (1930). Z. Geburtsh. Gynäk., 98, 291.

Hugounenq, M. L. (1899). J. Physiol. Path. gén., 1, 703. (1900a). Ibid., 2 . 1.

- (1900b). Ibid., 2, 509.

Iob, V., and Swanson, W. W. (1934). Amer. J. Dis. Child., 47, 302.

Koelker, A. H., and Slemons, J. M. (1911). J. biol. Chem., 9, 471.

Koneff, A. A., Nichols, C. W., Wolff, J., and Chaikoff, I. L. (1949). Endocrinology, 45, 242.

Lange, C. de (1900). Z. Biol., 40, 526.

Langstein, L., and Edelstein, F. (1917). Z. Kinderheilk., 15, 49.

McCance, R. A., and Widdowson, E. M. (1951). J. Physiol. 112, 450.

Macy, I. G., and Hunscher, H. A. (1934). Amer. J. Obstet. Gynec., 27, 878.

Masters, M., and Clayton, S. G. (1940). J. Obstet. Gynaec., 47, 437.

Michel, C. (1899). C.R. Soc. Biol., Paris, 51, 422.

Pratt, J. P., Kaucher, M., Moyer, E., Richards, A. J., 을 and Williams, H. H. (1946). Amer. J. Obstet. Gynec., 52, 665.

Pratt, J. P., Kaucher, M., Richards, A. J., Williams, H. H., and Macy, I. G. (1946). Ibid., 52, 402.

Schairer, E., and Rechenberger, J. (1943). Z. Kinder- $\vec{v}$ heilk., 64, 255.

Shohl, A. T. (1939). 'Mineral Metabolism.' New

Söldner (1903). Z. Biol., 44, 61.

Spray, C. M., and Widdowson, E. M. (1950). Brit. $F$ Nutrit., 4, 332.

Stearns, G., and McKinley, J. B. (1937). J. Nutrit., $13,143$.

Steinitz, F. (1904). Jb. Kinderheilk., 59, 447.

Streeter, G. L. (1920). Contr. Embryol. Carneg. Instn., No. 55, 11, 143. Publ. No. 274.

Thomas, K. (1911). Arch. Anat. Physiol., Physiol. Abt., p. 9.

Toverud, K. U. (1935). Acta paediatr., 17, Suppl. 1, p. 136.

Venn, J. A. J., McCance, R. A., and Widdowson, E. M. (1947). J. comp. Path., 57, 314.

Widdowson, E. M. (1950). Nature. 166, 626.

McCance, R. A., and Spray, C. M. (1950). Clin. Sci., 16, 113 . 